\title{
Coastal Bird Shelter: A New Avenue of Development of Ecotourism in Mumbai
}

\author{
Dr. Anis Ahmed B. Choudhery Ph.D. \\ Department of Zoology, G.M.Momin Women’s College, Bhiwandi, District Thane 421302, Maharashtra, India
}

\begin{abstract}
The present study was done to assess and propose a coastal bird shelter at the salt -pan areas of Mumbai .Coastal birds are an integral part of coastal ecosystems, which nowadays are subject to severe environmental pressures due to heavy encroachments, inlets of domestic and industrial pollution near coastal areas in creeks and sea, expansion of human population at cost of mangroves and absence of shelter for birds. We have already lost hundreds of species of bird since last century and there is urgent need of conservation of these entities. There are total of two hundred and twenty-three species of coastal birds were recorded from the coastal wetlands of India, which is belonging to 30 families under nine orders. The highest number of bird species observed at East coast, followed by West coast and Andaman \& Nicobar Islands. The data highlight the importance of the coastal wetlands of India as a strategic site, as well as the urgent need for it conservation, mostly for migratory birds during winter seasons. The present study is conducted in Bombay Jenkin Salt-Work, Bhandup, it occupies about 500 acres along with Thane creeks near the heaviest human settlement of Mumbai suburban. During present study hundreds of species of birds including flamingo, seagulls Oriental Stork, Black-headed Ibis, Greater Spotted Eagles, White-bellied Sea-eagle, Eurasian Curlew, Black-tailed Godwit etc had been observed. It included domestic as well as migratory birds. The present study provides the occurrence of coastal birds of in study area during my research period and explore the possibility to build a coastal bird shelter of around 3 sq.km in salt-pan areas without disturbing salt-production along the eastern highway in Bhandup and Mulund suburban areas near Thane creek to promote conservation of these Birds and ecotourism.
\end{abstract}

Keywords: Ecotourism, salt-works, migratory birds, Conservation, Coastal Bird Shelter

\section{Introduction}

Ecotourism is: "Responsible travel to natural areas that conserves the environment and improves the well-being of local people." (TIES, 1990). ${ }^{1}$ Ecotourism is about uniting conservation, communities, and sustainable travel. According to David Weaver (2001) Ecotourism is a form of tourism that is understood to be based primarily on naturebased attractions, learning - centered and conducted in a way that makes every reasonable attempt to be environmentally, socio-culturally and economically sustainable. ${ }^{2}$. It offers countries new opportunities for small-enterprise investment and employment and increases the national stake in protecting their biological resources.

Many countries like Australia, South Africa, America, Brazil, Nairobi, etc have secured their vast ecosystem with the implementation of ecotourism. Even many smaller countries like Malaysia, Maldives, Sri Lanka, Thailand, Indonesia etc have now gone far ahead with respect to developing their coastal beaches into a major ecotourism and marine tourism destination. India too is developing some parts of its states as ecotourism spots. Mumbai is one of most modern city of India; it captures the spirit of the changing pace set by liberalization and modernization. State wise the highest number of foreign tourist receives by Maharashtra in the country with nearly 4.8 million tourist arrivals in 2011 (Maharashtra Tourism Corporation annual report 2012) ${ }^{3}$ and Mumbai city plays largest contribution in this. Most of them do come to Mumbai to see many tourist sites in Mumbai.

There are more than 95 most popular tourist site in Mumbai like Gateway of India, Chowpatty Beach, Elephanta island, Haji Ali, Marine Drive, Band Stand, Sanjay Gandhi national parks , Kaneri caves, Essel world, Sidhivinayak Temple, Juhu Beach, Museum, Asiatic library, Hanging Garden etc.

In addition to this since last decades hundreds of private companies and individuals initiated ecotourism and agrotourism by developing Concept Gardens, Farm Houses, EcoFarms and Agro-farms nearby Mumbai suburbs. Ecotourism here includes bird watching, hiking or tracking on mountains, river rafting etc.

\section{Salt-Pans and salt production cycle}

In Mumbai Salt pans occupies 5378 acres at different coastal areas like Dahisar, Mira Road, Vasai, Virar, Bhandup, Nahur, Mulund, Vikroli, Turbhe, Wadala, Chembur and Anik .The present study was conducted in Jenkin salt pans which occupies around 500 acres and utilized only for salt production in Bhandup. ${ }^{4}$

The entire Bhandup salt works lays on both sides of the eastern highway near Thane creek, which lies extending between that 190-001 to 190-151 and long 720-551 to 730.00E.

Jenkin and Arther salt production area is situated to both side of eastern highway from Vikroli to Mulund which occupies 500 acres. Area is surrounded by huge colony of lush mangroves.

Salt curing in saltpans takes place during February-May and crude salt is extracted during summer. During the remaining part of the year, no other activity is conducted.

Salt pans consists of series of rectangular beds, each bed bounded on all four sides and joined to the next one through an opening in the common bund. A sluice gate in one bund

Volume 9 Issue 7, July 2020

www.ijsr.net

Licensed Under Creative Commons Attribution CC BY 


\section{International Journal of Science and Research (IJSR) \\ ISSN: 2319-7064}

ResearchGate Impact Factor (2018): 0.28 $\mid$ SJIF (2019): 7.583

of the first bed allows influx of saline water from a creek during high tides.

Here the water is allowed to evaporate. As the water evaporates, it is allowed to enter into the next tank where it crystallizes. Salt crystals are sprinkled in the last tank to initiate and catalyze the crystallization process. Entire saltpan zone is divided into 6 regions.

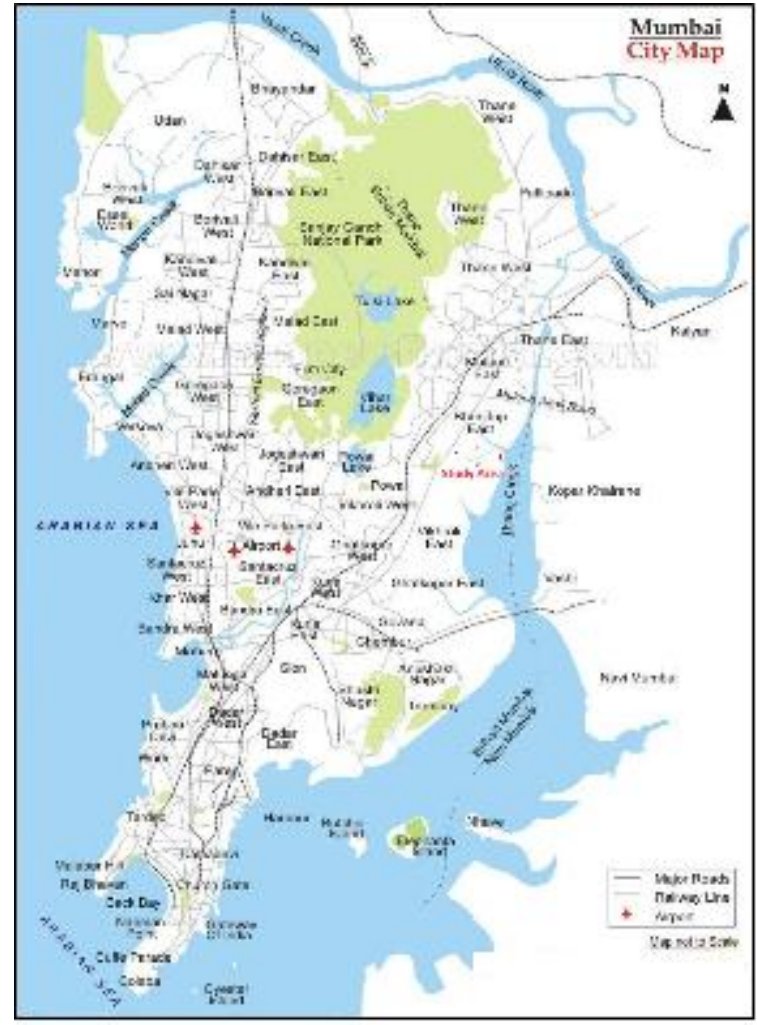

Construction of salt-pans: Although sea salt is manufactured extensively by solar evaporation but the process varies from place to place. In salt-pans around Mumbai the enclosed area is divided into following parts.

1) R1- Khajina or main reservoirs,

This is an area from where source of water is taken into the saltpan region. Thane creek is source of water in Jenkin Saltpan.

2) R2- Tapwanee or condensor.

During high tide, an influx of sea water occurs (water source), which enters the next region of the reservoir pans. Water is kept here for 1 to 2 days water is pumped into next region

3) R3-Ghans or feeding channels.

This region has less depth and high salinity after attaining a required salinity, water is flashed in to next region

4) R4- Crystallizer or space where salt is made.

These are smaller rectangles with lesser depth and very high salinity.

5) R5- Rasghan or channel for removing bitterns after salt manufacture.

Storage platform

The levels of these different parts of the salt works are so adjusted that the Khajina can be filled at each high water spring by gravity. From the Khajina the brine flows slowly into the tapewanees and when the correct density is reached it is led into crystallizes through the feeding channels. The storage platform is generally located by the side of the creek through which sea water flows into the reservoir.

\section{Process of salt production}

Immediately after the rain the outer and inner embankments are cleaned and repaired. After removing silt from the beds of the crystallizers they are trodden and beaten with wooden reamers till they become water tight. Actual salt formation begins at the end of December and till the rains set in the first or second week of June. The work comes into full production in the latter months and May.

During the fortnightly (from December to March on full moon day) high tides sea brine is admitted into reservoir and allowed to remain there for three to four days for storage as per the requirements. Some time there is need of pump for raising the water depending upon the height of the tide.

Important Hydrological parameter of R2 and R3 or Condenser as recorded during my Ph.D work (2019).

\begin{tabular}{|c|c|c|c|c|c|c|c|}
\hline $\begin{array}{c}\text { Hydrological } \\
\text { Parameter } \\
\text { (Average })\end{array}$ & December & January & February & March & April & May & June \\
\hline $\begin{array}{c}\text { Temperature } \\
\left(\mathrm{C}^{\circ}\right)\end{array}$ & 26.2 & 23.5 & 25.2 & 31.2 & 31.2 & 32.5 & 30 \\
\hline $\mathrm{PH}$ value & 7.7 & 7.8 & 8.10 & 7.5 & 7.20 & 7.30 & 7.2 \\
\hline $\mathrm{DO} \mathrm{mg} / \mathrm{l}$ & 4.9 & 4.2 & 4.10 & 3.30 & 2.83 & 1.86 & 1.75 \\
\hline $\mathrm{CO} 2 \mathrm{mg} / \mathrm{l}$ & 4.15 & 4.40 & 4.30 & 4.10 & 3.80 & 3.75 & 3.20 \\
\hline Salinity/ PPT & 29.30 & 37.96 & 42.30 & 50.36 & 52.10 & 55.18 & 58.60 \\
\hline
\end{tabular}

\section{Vegetation at salt-Pans}

Saltpans are surrounded by mangroves and other euryhaline plants. The entire area is surrounded by a marshy land which shows a characteristic growth of mangroves Avicennia alba mixed with Salvadora persica, Acanthus ilicifolius. The halophytes growing along the boundary of reservoirs are species of Sueda and Seasuvium. Seasuvium is consumed as vegetable by local people. Halophytes grow and complete their life cycle in habitats having high salt content. In fact, in many halophytes the growth is enhanced by salinity, though they can grow even in the absence of high salt contents. ${ }^{5,6}$

Phytoplankton of the reservoirs includes the different types of diatoms and algae, which form the first link in the food chain. Diatoms are plenty in both R1 R2 and R3. The dense growth is during January, February March and April. The different diatoms are Coscinodiscus Diploneis Navicula, Cyclotella, Synedra, Gyrosigma, Pleurosigma, Fragilaria, and Melosira.

Common algae growing in the reservoirs are Enteromorpha, Rhizoclonium, Oscillatoria and Cladophora. ${ }^{8}$

Algae play a significant role in the ecosystem of salt-pans by adding large quantities of organic matter to the reservoir water and by modifying the $\mathrm{pH}$, alkalinity color, turbidity and the radioactivity of the water.

By the end of April in R3, R4 and R5 due to high water temperatures and increase in salinity of water most of the 


\section{International Journal of Science and Research (IJSR) \\ ISSN: 2319-7064}

ResearchGate Impact Factor (2018): 0.28 | SJIF (2019): 7.583

algae wither and die. They start floating at the surface and accumulate at some places in the reservoirs in the form of patches.

\section{Important Fauna of Salt Pans}

The most hyper saline Fauna may be distinguished into two categories viz. the animals permanently inhabiting the saltpans and the animals visiting the area for procuring food and for some other reasons.

In this second group one can include crabs, some snakes and the birds. Since the water is shallow in the salt-pans it is easier for them to secure their food.

Bacteria, Diatoms, Ciliates, Nematodes, Insect (Mosquito larvae \& pupae), Chironomous larvae, Copepods, Amphipods, Mysids Prawns Gastropod larvae, Potamides, Small Gastro-pods and Bivalves, Fish eggs, Fish larvae Fish Tilapia) are few animals found in population density in different areas of the saltpans. ${ }^{9}$

Among these Fabria salina, mysids and insect larvae particularly chironomus larvae are prevalant. Indomysis annandale $i$ is the predominant mysid of the area. ${ }^{10}$

In macrofauna the mollusc, Potamides cingulatus is the only dominant one. Apart from this there are some tiny fresh water gastropods and bivalves living on the algae at some places. These forms must have invaded the area during rainy season. A few live specimens of Katalysia opama are recorded. Excepting these, the area showed only the empty scattered shells of different molluscs probably brought along with the tidal waters.

Permanently occuring fish in the reservoirs is Tilapia mossambica. It is one of the hardiest fishes which can adapt to any adverse condition. Among the occasionally found fishes in the reservoirs are Gobius ocellatus, Boleopthalmus dussumeri, Mugil dussumeri, Mugil belanak and Clupea lile, etc. Boleopthalmus dussumeri is a semi terrestrial fish.

Prawns predominantly present are Metapenaeus monoceros. The other few species of prawns belonging to family Palaemonidate are also present occasionally. ${ }^{11}$ The Chironomus are consumed in great quantities by fishes as well as the birds visiting this place. Sarotheroden (Tilapia) mossambica (Peters) is a native of South Africa and is known as African mouth brooder. It was introduced into Maharashtra from Ceylon. It is normally an inhabitant of fresh water but thrives well in estuarine and saline waters. It is one of the most hardiest fish. It breeds almost throughout the year. It is economically important, since it is a popular edible fish of the native people. It is one of the species recommended for aquaculture in coastal areas of our country, since it is a quick growing species and can establish itself successfully in a variety of environmental conditions. 12,13

\section{Birds of Salt-pans}

The birds were seen around the reservoirs and primary stage condensers. They feed mostly on small insects, their larvae, chironomides, mysids, small molluscs, fish, crabs, etc.
Two categories of birds can be mentioned, namely, permanent visitors and occasional visitors.

The permanently visiting birds of the area are -

Cattle egret - Bubulcus ibis (Linnaeus)

Jungle crow - Corvus macrorhynchos Wagler

House crow - Corvus splendens Vieillot

Common sand piper - Tringa hypoleucos (Linnaeus)

Cattle egret - Bubulcus ibis (Linnaeus) Common name Surkhia bagla

Pure white plumage with the yellow bill. The cattle egrets visit this place in large numbers from the nearby places, where they siege, walking or running along the sides of the reservoirs.

The occasional bird visitors are

Little cormorant - Phalacrocoax niger (Vieillot)

Pond Heron - Ardeola gravii (Sykes)

Small blue kingfisher - Alcedo atthis (Linnaeus)

Phalacrocorax niger (Vieillot) (Pan - Kowwa)

It is a black duck like water bird of the size of jungle crow. It has a compressed bill which is sharply hooked at the tip. It captures exclusively fish and its larvae, which it chases and captures under water.

Ardola gravii (Sykes) (Andha bagla). It is occasionally seen. Small sized, with deep rust coloured underparts, short stumpy tail and long, straight, pointed bill. It feeds on small fish, insects and larvae.

A report published in daily newspaper DNA 12, 2013 , "18 species migratory birds to spot in Mumbai before March ends". In same seasons more than 20000 flamingo, thousands of Herons, Ibis, Tern, cormorant, Black-tailed Godwit, Brown-headed Gulls, Egrets, Spotted Redshank including Whimbrel, Black-tailed and Bar-tailed Godwits, Terek Sandpiper, Sanderling, Curlew Sandpiper, Avocet, Heuglin's, Pallas's, Yellow-legged, Brahminy Kite were spotted.

\section{Conclusion and Suggestion}

\section{Possibility of Coastal Bird Shelter}

1) Throughout salt-production season from December to April and May, these 500 acres of land can be developed into Coastal Bird Shelter without disturbing salt-production and mangroves colony. As enough food for birds is available in R2 and R3 regions throughout the seasons. With little modification this zone is capable of attracting domestic birds as well as migratory birds.

2) Construction of freshwater pool and plantation of trees are needed in the surrounding areas for providing support to avian fauna and which can be easily done by the authorities.

3) The International Union for Conservation of Nature's (IUCN's) endangered list includes several bird species

\section{Volume 9 Issue 7, July 2020}




\section{International Journal of Science and Research (IJSR) \\ ISSN: 2319-7064}

ResearchGate Impact Factor (2018): 0.28 $\mid$ SJIF (2019): 7.583

found in Mumbai, including the Lesser Flamingo, Malabar Pied Hornbill, Black-headed Ibis, Pallid Harrier, Black-bellied Tern and White-ramped Vulture. All these birds can be easily invited to present salt-pans by creating Coastal Bird Shelter we can also serve in the protection of these endangered species.

4) Decent revenue can be expected from the bird watchers which can be further utilize for the development of the coastal Bird Shelter.

5) Educating the public about birds is the most important method of implementing conservation. The general public should appreciate and realize the importance of birds. Teaching on birds by various methods (posters, talks, audio-visual aids and field outings) can be effective in laying the basic foundation.

6) To develop locally based education programmes for students and the general public to better protect the species on their wintering grounds. Emphasis in these programmes should be given to the ecology of the area, changing land use patterns and efforts to protect migratory birds. should be taken on a regular basis to allow long term monitoring of changes in nutrient levels and other parameters.10. Promote cooperation with government and non-government organizations to share their research experiences.

7) An integrated management plan should be earmarked and implemented subsequently. The major emphasis should be given on participation, evaluation and monitoring by local communities.

8) Conduct coordinated international studies to understand better timing of migration, the numbers involved, flight behaviours and climatic influences on migration patterns.

9) Eco-tourism should be encouraged in the area to help improve the local economy.

10) Evaluate and maintain conditions suitable for migratory and other bird species. Conduct research on the biology and ecology of important migratory birds. Establish wildlife information / education centre.

11) So, an integrated approach and increased co-operation resulting in the rational use of this saltpan resource leading to improved standards of living around this saltpan and increased recreational facilities is recommended.

\section{Acknowledgements}

The authors are thankful to Guide Dr. S.G. Yeragi former HOD of Zoology K.J. Somaiya College, Dr. Pramood Salaskar, the environmental scientist and the villagers of nearby coastal areas of Bhnadup.

\section{References}

[1] TIES , 1990 , The International Ecotourism Society (TIES)

[2] David Weaver , 2001, Ecotourism page 80-82

[3] Govt of Maharashtra, 2012, Annual Report Maharashtra tourism corporation report

[4] Aggarwal S. C., 1938, The Salt Industry in India
[5] Flowers et al. 1977,, 1977, The mechanism of salt tolerance in halophytes, Annual Review of Plant Physiology January 1977, 89-114

[6] Greenway and Munns, 1980, Mechanisms of Salt Tolerance in Nonhalophytes, Annual Review of Plant Physiology 31:149-190 • June 1980

[7] APHA, 1985, Standard method for examination of water and waste water $16^{\text {th }}$ edition, Washington

[8] Bhattacharya S. S., 1965, Salinity and thermal tolerance of Marine planktons. Ph. D. Thesis Univ. of Bombay

[9] Chhapgar B. F. , 1957, Marine crabs of Bombay State. Contribution No. 1 of the Taraporevala Marine Biological Station.

[10] CMFRI, 1986, July - September - Newletter - Prawn culture in salt - pan areas - A profitable venture.

[11] Cernelius, PFS, 1972, Thermal acclimation of some intertidal invertebrates J. Exp. Mar. Biol. Soc. 9 : 43 53

[12] Deshmukh C.P, 1989, Ecology of saltpans of Mulund. Mphil, University of Mumbai.

[13] Evans R. G., 1948, The lethal temperatures of some common British literal molluscs. J. Animal Ecol. 17: $165-173$.

Volume 9 Issue 7, July 2020

www.ijsr.net

Licensed Under Creative Commons Attribution CC BY 